\title{
Correction: Vascular geometry of the extracranial carotid arteries: an analysis of length, diameter, and tortuosity
}

Choudhry FA, Grantham JT, Rai AT, et al Vascular geometry of the extracranial carotid arteries: an analysis of length, diameter, and tortuosity. Journal of NeuroInterventional Surgery 2016;8:536-540.

In table 1 of this proof there are some incorrect data entries. In the Vessel row, the Left and Right headings should both read $(n=100)$. In the Tortuosity row, the data in the middle column should be $1.2( \pm 0.1)$. This means that the result in the p value column should read $<0.0001$.

(c) Article author(s) (or their employer(s) unless otherwise stated in the text of the article) 2018. All rights reserved. No commercial use is permitted unless otherwise expressly granted.

J Neurolntervent Surg 2018;10:e9. doi:10.1136/neurintsurg-2015-011671 corr1

A Check for updates 